\title{
SOURGRASS INTERFERENCE ON SOYBEAN GROWN IN BRAZILIAN CERRADO $^{1}$
}

\author{
GUILHERME BRAGA PEREIRA BRAZ ${ }^{2 *}$, ALINE GUIMARÃES CRUVINEL ${ }^{2}$, ALAN BRUNO CANEPPELE $^{2}$, \\ HUDSON KAGUEYAMA TAKANO ${ }^{3}$, ALESSANDRO GUERRA DA SILVA ${ }^{2}$, \\ RUBEM SILVÉRIO DE OLIVEIRA JÚNIOR ${ }^{4}$
}

\begin{abstract}
Sourgrass (Digitaria insularis) is one of the main species causing significant losses in Brazilian soybean production systems. Thus, this paper aimed to evaluate sourgrass interference on soybeans grown under Cerrado conditions. Three field experiments were conducted, of which the first two (E1 and E2) simulated sourgrass after pre-sowing burndown, using plants already emerged by the time soybeans were sown; whereas the third (E3) simulated both sourgrass and soybeans emerged simultaneously. Both E1 and E2 were conducted in a randomized complete block design (RCBD) with five treatments based on sourgrass infestation densities $\left(0,2,4,6\right.$, and 8 plants $\left.\mathrm{m}^{-2}\right)$ and four replications. In turn, E3 was also carried out in an RCBD but with treatments arranged in a $2 \times 5$ factorial and four replications. The first factor comprised two soybean cultivars, while the second was sourgrass density levels, just as in E1 and E2. The results showed that increasing sourgrass densities reduced soybean yield regardless of the plant growth stage when the crop was sown. Yield losses were higher when sourgrass plants were already established by the time soybean was sown. Soybean yield losses reached up to $80 \%$ under higher sourgrass infestation levels.
\end{abstract}

Keywords: Digitaria insularis. Glycine max. Weed-crop competition. Weed density.

\section{INTERFERÊNCIA DO CAPIM-AMARGOSO NA CULTURA DA SOJA NO CERRADO BRASILEIRO}

\begin{abstract}
RESUMO - Entre as espécies que tem causado maiores prejuízos nos sistemas brasileiros de produção de soja, está o capim-amargoso. Neste contexto, o objetivo deste trabalho foi avaliar o efeito da interferência do capimamargoso na soja cultivada em condições de Cerrado. Para tanto, foram instalados três experimentos à campo, sendo dois simulando área com falhas na dessecação de capim-amargoso na pré-semeadura da soja, com plantas remanescentes desta espécie (E1 e E2) e um no qual simulou a emergência do capim-amargoso ocorreu de forma simultânea a da soja (E3). No E1 e E2, o delineamento utilizado foi o de blocos casualizados (DBC), sendo avaliados cinco tratamentos compostos por densidades crescentes de capim-amargoso $(0,2,4,6$ e 8 plantas por $\mathrm{m}^{2}$ ) e quatro repetições. No E3, também foi utilizado o DBC, estando os tratamentos dispostos em arranjo fatorial $2 \times 5$, com quatro repetições. O primeiro fator foi composto de duas cultivares de soja de ciclo distinto; enquanto que no segundo foram simuladas densidades de capim-amargoso em convivência com a soja, sendo adotadas as mesmas do E1 e E2. O aumento de densidade de capim-amargoso em convivência com a soja proporciona redução na produtividade da cultura, independentemente se estas plantas estavam emergidas na ocasião da semeadura ou se a infestação foi estabelecida após a emergência da soja. A intensidade de redução na produtividade da cultura é maior quando as plantas de capim-amargoso já se encontram entouceiradas na área na ocasião da semeadura da soja, chegando a reduções próximas de $80 \%$ na maior densidade de infestação.
\end{abstract}

Palavras-chave: Digitaria insularis. Glycine max. Matocompetição. Densidade de planta daninha.

\footnotetext{
${ }^{\text {"Corresponding author }}$

${ }^{1}$ Received for publication in 07/22/2020; accepted in 01/27/2021.

Paper extracted from the master dissertation of the second author.

${ }^{2}$ Agronomy College, Universidade de Rio Verde, Rio Verde, GO, Brazil; guilhermebrag@gmail.com - ORCID: 0000-0002-0396-7140, aline.guimaraes@gapescna.agr.br - ORCID: 0000-0001-5668-6505, alancaneppele.agro@outlook.com - ORCID: 0000-0001-7670-8708, silvaag@yahoo.com.br - ORCID: 0000-0002-9556-0312.

${ }^{3}$ Mode of Action Center of Expertise, Corteva Agriscience, Indianapolis, IN, EUA; hudsontakano@gmail.com - ORCID: 0000-0002-80183868 .

${ }^{4}$ Agronomy Department, Universidade Estadual de Maringá, Maringá, PR, Brazil; rubem.oliveirajr@gmail.com - ORCID: 0000-0002-5222 -8010 .
} 


\section{INTRODUCTION}

Weed resistance to herbicides has been causing financial losses to growers due to weed interference and increased production costs (HEAP; DUKE, 2018). In Brazil, costs of herbicide resistance management in soybeans are estimated to be approximately 1.25 billion dollars annually, and this could reach up to 2.3 billion dollars, including yield losses caused by weed interference (ADEGAS et al., 2017).

To date, there are 50 cases of herbicideresistant weeds in Brazil with a significant increase of glyphosate-resistant biotypes in the past 15 years (HEAP, 2020). In general, the evolution of glyphosate resistance has typically increased problems, especially because this herbicide is one of the most used in agriculture and sue to the broad adoption of genetically engineered crops able to withstand post-emergence glyphosate applications (DUKE; POWLES; SAMMONS, 2018). In South America, for instance, more than $90 \%$ of soybean fields are cultivated with glyphosate-resistant crops (PETERSON et al., 2018). Therefore, any weed species evolving glyphosate resistance can become a significant problem to agriculture in those areas (SAMMONS; GAINES, 2014).

Sourgrass (Digitaria insularis) is one of the main species that have evolved resistance to glyphosate in Brazil (LÓPEZ-OVEJERO et al., 2017; SOUSA et al., 2020). It belongs to the Poaceae family and was first documented as glyphosateresistant in 2005 and 2008 in Paraguay and Southern Brazil, respectively (CARVALHO et al., 2011; HEAP, 2020). Sourgrass is currently widespread across different regions of Brazil, especially due to its rapid dissemination, which can be through propagule movement or independent selections (LOPEZ-OVEJERO et al., 2017; TAKANO et al., 2018).

In addition to glyphosate, resistance to acetylcoenzyme A carboxylase (ACCase) inhibitors evolved in sourgrass populations in Mato Grosso do Sul State (HEAP, 2020); therefore, resistant biotypes have been selected for the main alternative mechanism of action for sourgrass post-emergence control. Besides herbicide resistance, sourgrass is considered an aggressive weed with a perennial life cycle, rhizome and clump formation, and high levels of seed production and dissemination (GEMELLI et al., 2012). These characteristics demonstrate the importance of understanding sourgrass interference on crops so that effective management practices could be developed.

In soybeans, losses due to sourgrass interference are estimated to reach up to $37 \%$ for a weed density of 6 plants $\mathrm{m}^{-2}$ (GAZZIERO et al.,
2019). Although this is interesting information, results from observational studies cannot be inferred for larger populations. Other factors can contribute to negative effects associated with sourgrass interference on soybean. Therefore, it is clear the need for a study with treatments randomly allocated in experimental units to precisely quantify sourgrass effect on soybean development and yield.

Differential responses among cultivars have been observed for weed interference on soybeans (MONKS; OLIVER, 1988). Typically, shorter-cycle cultivars are mostly affected by stresses because they have less time to recover from it (LAMEGO et al., 2004; NORDBY; ALDERKS; NAFZIGER, 2007). This hypothesis is associated with factors determining weed interference levels, as coexistence time between crops and weeds directly affects the intensity of crop losses. In general, the longer the crops coexist with weeds, the greater the yield losses (RAIMONDI et al., 2017).

Based on the above, the objective of this research was to evaluate the effect of sourgrass interference on soybean cultivars with distinct cycles and cultivated under the Brazilian Cerrado edaphoclimatic conditions.

\section{MATERIAL AND METHODS}

Two experiments were conducted to evaluate weed interference on soybean yield at increasing sourgrass densities, simulating areas where plants survived a pre-sowing burndown treatment. Both experiments were conducted in the city of Paraúna (Goiás), at the coordinates and altitude of $17^{\circ} 33^{\prime} 23.72^{\prime}$ 's, $50^{\circ} 68^{\prime} 64.96^{\prime} \mathrm{W}, \quad 634 \mathrm{~m}$; and $17^{\circ} 31^{\prime} 34.17^{\prime \prime} \mathrm{S}, \quad 50^{\circ} 70^{\prime} 21.14^{\prime \prime} \mathrm{W}, \quad 658 \mathrm{~m}$ for Experiment 1 (E1) and Experiment 2 (E2), respectively.

A third experiment (E3) was conducted to evaluate weed interference on soybean response to increasing sourgrass densities, simulating areas with no residual herbicide application. In this case, sourgrass and soybeans germinated simultaneously. This experiment was conducted in the city of Rio Verde (Goiás) at $17^{\circ} 47^{\prime} 18.67^{\prime}$ 'S; 5057'27.67' $\mathrm{W}$; $749 \mathrm{~m}$ altitude. All experiments were performed between October 2018 and March 2019.

The climate at the locations where experiments were conducted is classified as $A w$ type, according to Köppen's classification, which stands for a tropical climate with a dry season. These conditions typically have more intense rainfall in summer compared to winter (Climate-Data, 2020). Figure 1 shows the weather conditions within the experimental period, including average temperature and rainfall. 


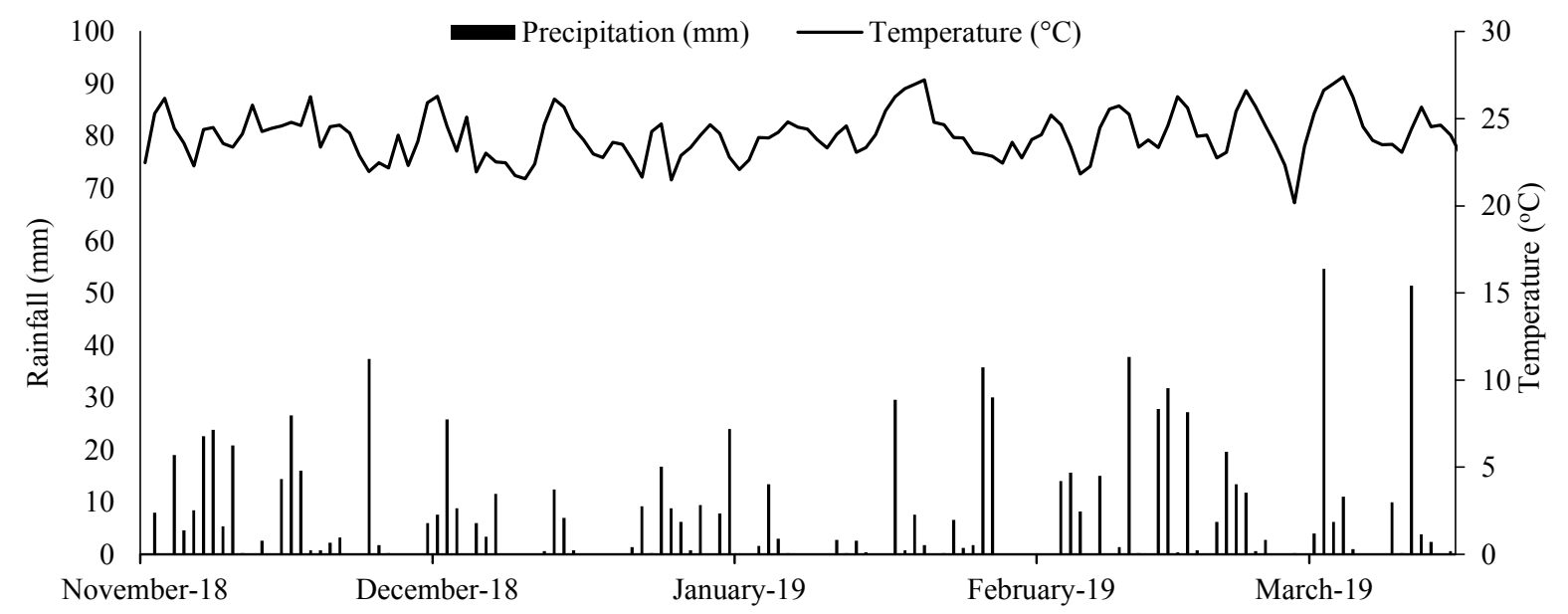

Source: INMET - Brazilian Institute of Meteorology - Rio Verde - GO.

Figure 1. Averages of temperature and rainfall throughout the experimental period for evaluation of sourgrass interference effect on soybeans. Paraúna and Rio Verde (Goiás), 2018/2019.

Before experiments were set, soil samples were collected $(0-20 \mathrm{~cm}$ depth layer $)$ from all experimental areas (E1, E2, and E3). Table 1 presents the soil physicochemical characteristics and soybean implementation data. Soybean cultivars were selected based on maturity group and economic relevance in Goiás State. To prevent soybean yield losses by pests and diseases, all experiments underwent phytosanitary treatments, assessing pest infestations weekly.

Table 1. Soil physicochemical characteristics in the experimental areas and soybean crop information. Paraúna and Rio Verde (Goiás), 2018/2019.

\begin{tabular}{|c|c|c|c|}
\hline & Experiment 1 & Experiment 2 & Experiment 3 \\
\hline & \multicolumn{3}{|c|}{ Soil physicochemical characteristic } \\
\hline $\mathrm{pH}\left(\mathrm{H}_{2} \mathrm{O}\right)$ & 5.7 & 5.6 & 5.3 \\
\hline Organic matter $\left(\mathrm{g} \mathrm{kg}^{-1}\right)$ & 43.4 & 40.1 & 37.6 \\
\hline Clay $\left(\mathrm{g} \mathrm{kg}^{-1}\right)$ & 55.5 & 50.5 & 48.5 \\
\hline Silt $\left(\mathrm{g} \mathrm{kg}^{-1}\right)$ & 20.0 & 18.5 & 12.0 \\
\hline \multirow[t]{2}{*}{ Sand $\left(\mathrm{g} \mathrm{kg}^{-1}\right)$} & 24.5 & 31.0 & 39.5 \\
\hline & \multicolumn{3}{|c|}{ Crop information } \\
\hline Sowing date & $23 / 10 / 2018$ & $01 / 11 / 2018$ & $19 / 10 / 2018$ \\
\hline Emergence date & $28 / 10 / 2018$ & $06 / 11 / 2018$ & $24 / 10 / 2018$ \\
\hline Cultivar & Syn15640 IPRO ${ }^{(\mathbb{B})}$ & ST797 IPRO $^{(\mathbb{R}}$ & Garra $^{(\mathbb{R}}$ and ST797 IPRO $^{(\mathbb{R})}$ \\
\hline Maturity group & 6.9 & 7.9 & 6.3 and 7.9 \\
\hline Row spacing (m) & 0,50 & 0,50 & 0,50 \\
\hline Soybean density & 20 & 16 & 19 and 15 \\
\hline Fertilization $\left(\mathrm{kg} \mathrm{ha}^{-1}\right)$ & 200 & 200 & 430 \\
\hline Formulated fertilizer & $07-40-20$ & $07-40-20$ & 04-20-18 \\
\hline Harvest date & $01 / 02 / 2019$ & $13 / 03 / 2019$ & $06 / 02 / 2019$ and $26 / 02 / 2019$ \\
\hline
\end{tabular}

Apart from the emerged sourgrass plants, all other weeds were eliminated by hand-weeding so that only the effect of sourgrass density interference on soybeans was evaluated. Sourgrass plants used in all experiments were glyphosate-resistant, which was confirmed by spraying plants with a previously determined discriminatory rate (LÓPEZ-OVEJERO et al., 2017).
Experiments 1 and 2. Simulation of areas with sourgrass survival after soybean pre-sowing burndown

The experimental design for both experiments was a randomized complete block with five treatments and four replications. Treatments were composed of increasing sourgrass densities: $0,2,4$, 
6 , and 8 plants $\mathrm{m}^{-2}$. Experimental units comprised five 6-m-long soybean rows spaced $0.5 \mathrm{~m}$ apart (a total of $\left.15 \mathrm{~m}^{2}\right)$. The useful area $\left(7.5 \mathrm{~m}^{2}\right)$ was considered as the center of each plot, excluding $0.5 \mathrm{~m}$ at the extremities.

Sourgrass densities in soybeans were simulated by selecting experimental areas with high weed infestation (@15 plants $\mathrm{m}^{-2}$ ). In both locations, sourgrass plants were manually removed until reaching the desired density in each experimental unit when soybeans were sown.

\section{Experiment 3. Simulation of areas with sourgrass and soybean plants emerging simultaneously}

The experimental design was a randomized complete block, and treatments were arranged in a $2 \times 5$ factorial with four replications. The first factor comprised two soybean varieties with different maturity cycles (Garra - early cycle; ST797 medium cycle). The second factor was increasing sourgrass densities: $0,2,4,6$, and 8 plants $\mathrm{m}^{-2}$. The experimental units $\left(12.5 \mathrm{~m}^{2}\right)$ were composed of five 5 -m-long soybean rows spaced $0.5 \mathrm{~m}$ apart. The useful area $\left(6 \mathrm{~m}^{2}\right)$ was considered as the center of each plot, excluding $0.5 \mathrm{~m}$ at the extremities.

To simulate increasing infestation levels, sourgrass seedlings were grown in flats (200 cell plastic flats with a volume of $15 \mathrm{~mL}$ per cell) and manually transplanted to the experimental units until reaching the desired density for each treatment. Seedling transplanting was done when sougrass was in a two-leaf growth stage and simultaneously to soybean planting.

\section{Response variables and statistical analysis}

To quantify the effect of treatments on soybean development, we evaluated the following variables: plant height at 14 and 35 days after crop emergence (DAE) and at harvest time; and SPAD chlorophyll index at 35 DAE. Plant height was measured with a graduated scale from the soil surface to plant apical meristem. The SPAD index was evaluated in the middle third of fully expanded trifoliate leaves, using a chlorophyll meter (Minolta SPAD-502, Osaka, Japan). For both plant height and SPAD index, five plants of each experimental unit were used.

Crop row closure (\%) was visually evaluated by rating the percentage of row space covered by plant canopy, in which $100 \%$ corresponded to total canopy row closure. Shoot dry mass was also evaluated by collecting five soybean plants per plot and drying them at $65^{\circ} \mathrm{C}$ for $72 \mathrm{~h}$ before weighting. Both crop row closure and shoot dry mass were assessed at 42 DAE.

By the time the crop was harvested, soybean density (only E3), first-pod height, number of pods per plant, and 100 seed weight were assessed. The density of soybean plants was quantified over $2 \mathrm{~m}$ of the useful area, and data were expressed as the number of plants $\mathrm{m}^{-1}$. First-pod height was quantified by measuring the distance between the soil surface and the first pod insertion point. These evaluations were performed in five plants per experimental unit. To quantify soybean yield, all plants within the useful area were manually harvested, threshed, labeled, and weighed after grain moisture was corrected to $13 \%$.

Statistical analysis was performed using the SISVAR software (FERREIRA, 2011). For all experiments, data were subjected to ANOVA and Ftest. For E1 and E2, when significant effects were observed for the sourgrass densities, a regression analysis was performed $(p<0.05)$. For E3, when significant effects were observed between each factor or for the interaction thereof, a regression analysis was also performed $(\mathrm{p}<0.05)$. However, differences between cultivars were presented individually.

\section{RESULTS AND DISCUSSION}

Experiments 1 and 2. Simulation of areas with sourgrass survival after soybean pre-sowing burndown

A linear increase in soybean height was observed by increasing sourgrass density for both locations at 14 and 35 DAE (Figure 2); therefore, soybean plants etiolated in response to the shading exerted by sourgrass plants. When coexisting with soybeans, weeds reflect light at a particular wavelength that makes soybean plants perceive they are under interference (MEROTTO JR. et al., 2002). Under these situations, before establishing competition for water, light, and nutrients, crops develop strategies to avoid being shaded by weeds, such as etiolation (LIU et al., 2009).

In addition to incurring unnecessary metabolic costs, etiolation usually reduces shoot diameters (CONSTANTIN et al., 2009), increasing crop susceptibility to lodging. When soybeans were artificially subjected to conditions that contribute to plant lodging, yield losses reached up to $30 \%$ (WOODS; SEARINGIN, 1977). Therefore, soybean areas under high sourgrass infestation will not only have grain yield potential compromised by competition with the weed but also due to plant lodging. 

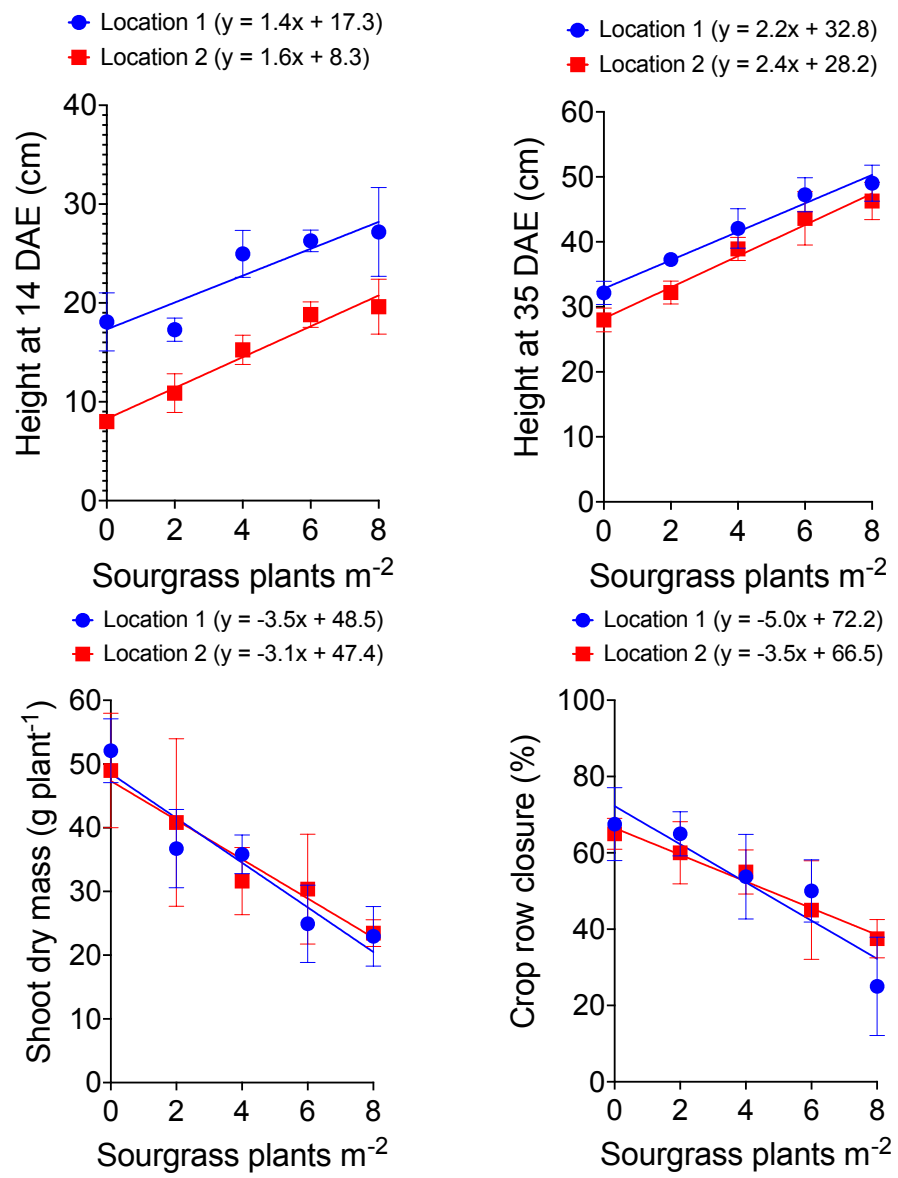

Figure 2. Plant height at 14 and 35 days after emergence (DAE), shoot dry mass and crop row closure in response to sourgrass infestation densities. Paraúna (Goiás), 2018/2019.

We found no significant interference effect of sourgrass on SPAD chlorophyll index in both locations (data not shown). Although the SPAD index showed no significant differences, soybean plants under weed interference had their chlorophyll contents reduced (EL-METWALLY; ELEWA; DAWOOD, 2017). This can be justified by soybean competition with sourgrass for nutrients available in the environment. Under nutrient deficiency, foliar chlorosis is commonly observed in plants, resulting in decreased SPAD indexes (ABDELHAMID; ELMETWALLY, 2008).

Soybean shoot dry mass decreased in response to increasing sourgrass infestation densities (Figure 2). By averaging over locations, soybean shoot dry mass decreased by $55 \%$ when soybeans coexisted with 8 sourgrass plants $\mathrm{m}^{-2}$. In most cases, a reduction in shoot dry mass results in negative consequences to grain yield since total leaf area is compromised. With reduced leaf area available for light interception and photosynthesis, chemical energy is not enough to be allocated for grain formation (RAMBO et al., 2003).

The combined effect of etiolation and dry mass reduction found in soybean plants resulted in lower crop row closure percentages under higher sourgrass infestation densities (Figure 2). Although crop row closure decreased linearly in both locations, such reduction was less intense for the early cycle soybean variety in Location 1 than in Location 2. A result that can be supported by the slope of the equations of these two locations.

Despite the possible edaphoclimatic differences between both locations, such a differential response between cultivars indicates that soybean cultivars with longer maturity cycles can be recommended to withstand sourgrass interference. Soybean cultivars with longer maturity cycles better resist initial weed competition, besides showing greater competitiveness when compared to short cycle ones (LAMEGO et al., 2004; NORDBY; ALDERKS; NAFZIGER, 2007).

First pod height was affected only at Location 1 , with a linear increase in response to higher sourgrass infestation densities (Figure 3). At a density of 8 sourgrass plants $\mathrm{m}^{-2}$, first pod height was 1.8 times higher than that of untreated control, without sourgrass plants. This might be associated with soybean etiolation when under competition. 
Location $1(y=0.85 x+8.53)$

Location 2 ( $y=16.65 n s)$

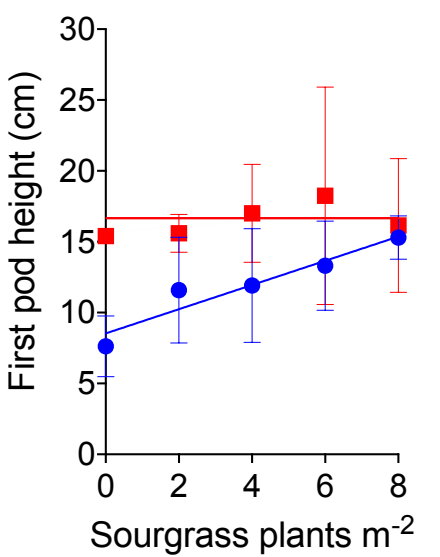

- Location $1(y=-1.8 x+30.1)$

Location 2 ( $y=47.55 \mathrm{~ns})$

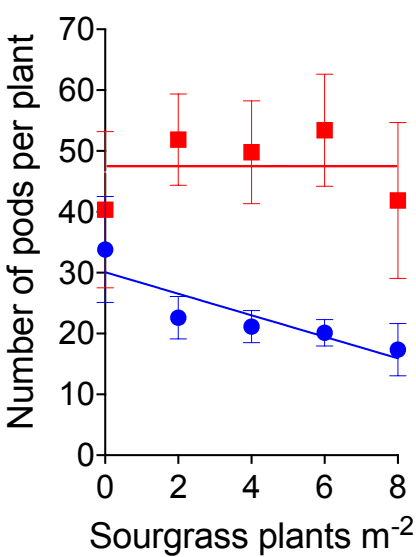

Location $1(\mathrm{y}=134+(3172-134) /(1+(\mathrm{x} / 1.46))$

Location $2(y=104+(3129-104) /(1+(x / 2.24))$

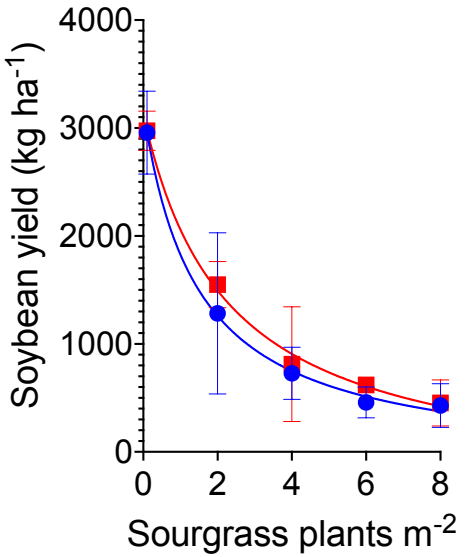

Figure 3. First pod height, number of pods per plant, and soybean yield in response to increasing sourgrass infestation densities. Paraúna (Goiás), 2018/2019.

In E1, as sourgrass density increased, the number of pods per plant reduced linearly (Figure 3). As pod number per plant is one of the yield components, any reduction can lead to crop yield losses. Each sourgrass plant reduced 1.8 pods per plant on average when they coexisted with soybeans, corresponding to a loss of approximately 720,000 pods $\mathrm{ha}^{-1}$. Another soybean yield component evaluated was 100-seed weight, which was not affected by increasing sourgrass infestation density (data not shown).

Soybean yield was significantly affected by sourgrass interference in both experiments. As sourgrass density increased, soybean yield decreased exponentially (Figure 3). Even with lower densities of sourgrass infestation, soybean yield was drastically reduced by weed interference. Therefore, there is no acceptable tolerance level to avoid loss of yield due to sourgrass interference. At a sourgrass density of 2 plants $\mathrm{m}^{-2}$ coexisting with soybeans, yield losses were 57 and $48 \%$ in E1 and E2, respectively. Under higher sourgrass densities (8 plants $\mathrm{m}^{-2}$ ), yield losses reached up to 86 and $85 \%$ in E1 and E2, respectively.

\section{Experiment 3. Simulation of areas with sourgrass and soybean plants emerging simultaneously}

No significant interaction was observed between soybean cultivars and sourgrass densities for plant height at 14 and $35 \mathrm{DAE}$. The isolated effect of these two factors was not significant either (data not shown). Table 2 displays the response variables showing significant differences between soybean cultivars.

Table 2. Behavior of soybean cultivars for each response variable evaluated. Rio Verde (Goiás), 2018/2019.

\begin{tabular}{lcccc}
\hline Response variable & \multicolumn{2}{c}{ Garra $^{(B)}$} & \multicolumn{2}{c}{ ST797 IPRO $^{(B)}$} \\
\hline SPAD index & 44.24 & $\mathrm{~b}$ & 46.21 & $\mathrm{a}$ \\
Plant height at harvest $(\mathrm{cm})$ & 70.84 & $\mathrm{~b}$ & 87.15 & $\mathrm{a}$ \\
First pod height $(\mathrm{cm})$ & 11.79 & $\mathrm{~b}$ & 17.45 & $\mathrm{a}$ \\
Number of pods per plant & 38.90 & $\mathrm{~b}$ & 82.10 & $\mathrm{a}$ \\
100 seeds weight $(\mathrm{g})$ & 15.75 & $\mathrm{a}$ & 11.50 & $\mathrm{~b}$ \\
\hline
\end{tabular}

Means followed by different letters in the column are significantly different by the F-test $(\mathrm{p}<0.05)$.

For SPAD index, plant height at harvest, first pod height, and the number of pods per plant, cultivar ST797 IPRO $^{\circledR}$ showed higher means compared to Garra ${ }^{\circledR}$. These differences are probably associated with the morphological characteristics of each cultivar. Varieties with longer maturity cycle tend to show greater plant height compared to those with shorter cycle (ZANON et al., 2015), thus increasing first pod height, which is consistent with our observations. The only response variable in which cultivar Garra ${ }^{\circledR}$ showed higher mean compared to ST797 IPRO ${ }^{\circledR}$ was 100 -seed weight.

Soybean shoot dry mass was affected as sourgrass density was increased, but no differences were observed between cultivars (Figure 4). Shoot dry matter accumulation had a linear response of up to $25 \%$ reduction at sourgrass density of 8 plants $\mathrm{m}^{-2}$ compared to the untreated control. Crop row closure 
was also linearly reduced in response to increasing sourgrass densities, with no differences in behavior between cultivars. These results are consistent with those for shoot dry mass because smaller plants tend to present a lower crop row closure.
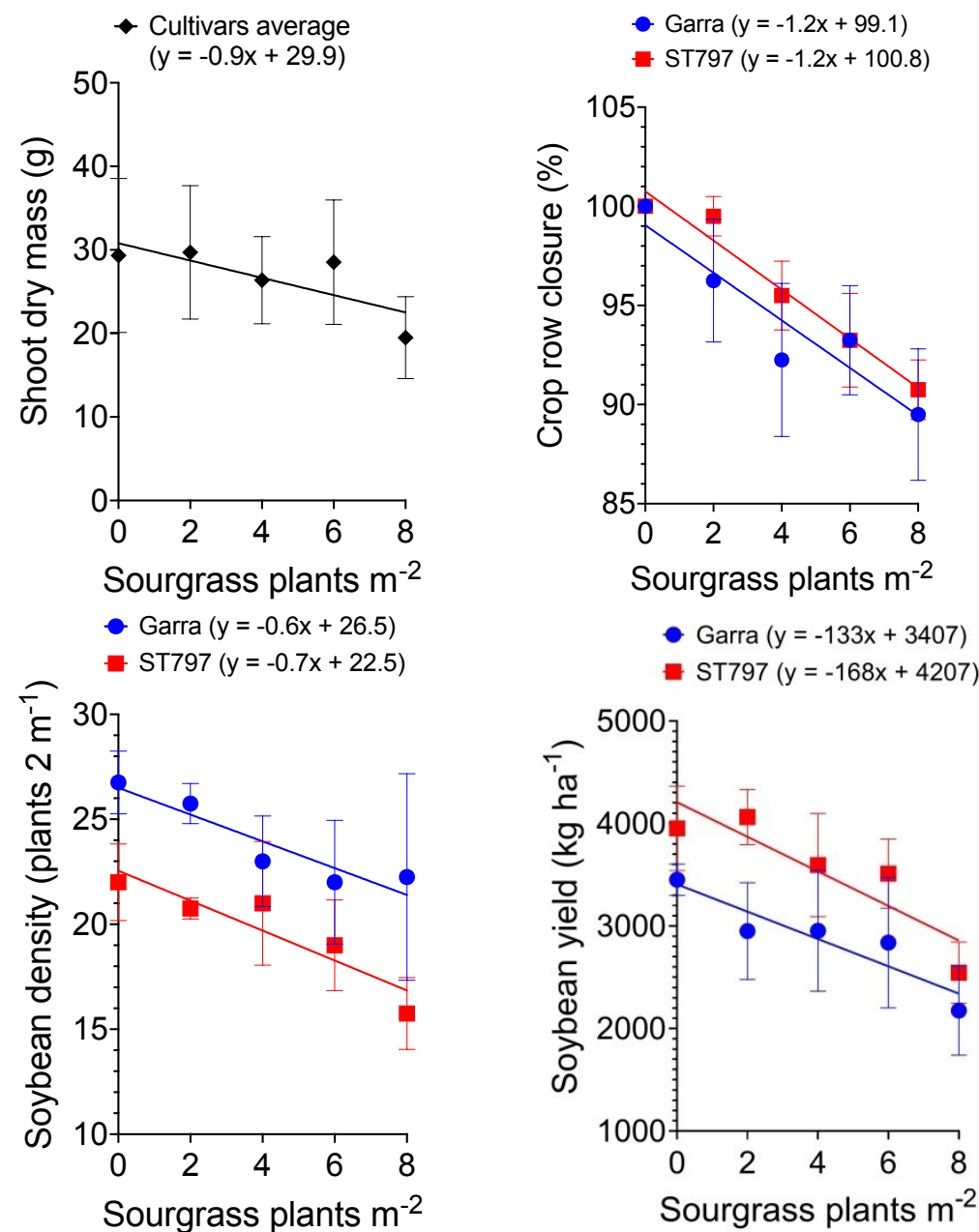

Figure 4. Shoot dry mass, crop row closure, soybean density, and soybean yield in response to increasing sourgrass infestation densities. Rio Verde (Goiás), 2018/2019.

Both cultivars showed higher mortality as the density of sourgrass increased, given a decrease in the density of soybean plants for both (Figure 4). Still, soybeans have phenotypic plasticity, which is associated with plant ability to compensate losses in grain production due to failures in population density (BALBINOT JÚNIOR et al., 2018). On the other hand, when the number of sourgrass plants $\mathrm{ha}^{-1}$ is reduced, a negative effect on crop yield can occur. Moreover, a low plant density can result in opportunities for weed emergence later in the season, compromising soybean harvest, yield, and weed management costs.

Soybean yield was linearly reduced in response to increasing sourgrass densities for both varieties (Figure 4). A maximum yield reduction was observed infestation by sourgrass reached 8 plants $\mathrm{m}^{-2}$ (1064 and $1344 \mathrm{~kg} \mathrm{ha}^{-1}, 31$ and $32 \%$ for cultivars Garra ${ }^{\circledR}$ and ST797 IPRO $^{\circledR}$, respectively).
Such losses in soybean yield demonstrate the importance of using pre-emergence herbicides (LÓPEZ-OVEJERO et al., 2019) and cover crops such as Congo grass (Brachiaria ruziziensis) (MAROCHI et al., 2018), which have lower costs when compared to the negative effects of sourgrass interference.

By comparing the results from all experiments, it is evident that surviving sourgrass individuals or plants already established in the field tend to cause higher yield losses than those emerging simultaneously with the crop. Such a behavior can be explained by sourgrass shading on soybean seedlings when the weed is already established. Moreover, when soybeans and sourgrass are emerging at the same time, the weed might be in a disadvantage as a result of its low initial growth rate (GEMELLI et al., 2012).

To the best of our knowledge, this is the first 
report of yield losses caused by sourgrass in a controlled experimental design. Regardless of the infestation level, either sourgrass density can cause intense yield losses in soybeans. These findings demonstrate the need to proceed with an efficient burndown treatment, along with other control methods, to allow soybean fields to start clean and free of weeds.

\section{CONCLUSIONS}

Increasing the density of sourgrass infesting soybean crops promotes yield losses regardless of whether sourgrass plants are already established or emerging simultaneously with soybeans. However, yield loss intensity is greater when sourgrass plants are already established (e.g., surviving a burndown treatment).

Yield losses can reach $32 \%$ when soybean and sourgrass plants are established simultaneously. The worst-case scenario occurs at a density of $8 \mathrm{~m}^{-2}$ sourgrass plants before soybean sowing, in which yield losses can reach up to $80 \%$.

\section{ACKNOWLEDGEMENTS}

To the Conselho Nacional de Desenvolvimento Cientifico e Tecnológico (CNPq) for funding this research (Project approved by Chamada Universal $\mathrm{n}^{\circ} 28 / 2018$ ) and to the University of Rio Verde (UniRV) for providing research scholarship to the first author.

\section{REFERENCES}

ABDELHAMID, M. T.; EL-METWALLY, I. M. Growth, nodulation, and yield of soybean and associated weeds as affected by weed management. Planta Daninha, 26: 855-863, 2008.

ADEGAS, F. S. et al. Impacto econômico da resistência de plantas daninhas a herbicidas no Brasil. 1. ed. Londrina, PR: EMBRAPA SOJA, 2017. 11 p. (Circular Técnica 123).

BALBINOT JÚNIOR, A. A. et al. Phenotypic plasticity in a soybean cultivar with indeterminate growth type. Pesquisa Agropecuária Brasileira 53: 1038-1044, 2018.

CARVALHO, L. B. et al. Detection of sourgrass (Digitaria insularis) biotypes resistant to glyphosate in Brazil. Weed Science, 59: 171-176, 2011.

CLIMATE-DATA. Clima Rio Verde. 2020. Disponível em: < https://pt.climate-data.org/america- do-sul/brasil/goias/rio-verde-4473/>. Acesso em: 06 jun. 2020 .

CONSTANTIN, J. et al. Sistemas de manejo de plantas daninhas no desenvolvimento e na produtividade da soja. Bragantia, 68: 125-135, 2009.

DUKE, S. O.; POWLES, S. B.; SAMMONS, R. D. Glyphosate - How it became a once in a hundred year herbicide and its future. Outlooks on Pest Management, 29: 247-251, 2018.

EL-METWALLY, I. M.; ELEWA， T. A. E.; DAWOOD, M. G. Response of soybean cultivars to weed control treatments. Agricultural Engineering International: CIGR Journal, 19: 159-165, 2017.

FERREIRA, D. F. Sisvar: a computer statistical analysis system. Ciência e Agrotecnologia, 35: 1039-1042, 2011.

GAZZIERO, D. L. P. et al. Estimating yield losses in soybean due to sourgrass interference. Planta Daninha, 37: e019190835, 2019.

GEMELLI, A. et al. Aspectos da biologia de Digitaria insularis resistente ao glyphosate e implicações para o seu controle. Revista Brasileira de Herbicidas, 11: 231-240, 2012.

HEAP, I. International survey of herbicide resistant weeds. 2020. Disponível em: <http:// www.weedscience.com>. Acesso em: 25 jun. 2020.

HEAP, I.; DUKE, S. O. Overview of glyphosate $\square$ resistant weeds worldwide. Pest Management Science, 74: 1040-1049, 2018.

LAMEGO, F. P. et al. Tolerância à interferência de plantas competidoras e habilidade de supressão por genótipos de soja - II. Resposta de variáveis de produtividade. Planta Daninha, 22: 491-498, 2004.

LIU, J. G. et al. The importance of light quality in crop-weed competition. Weed Research, 49: 217 224, 2009

LÓPEZ-OVEJERO, R. F. et al. Residual herbicides in Roundup Ready soybean: A case study in multiple years and locations with Ipomoea triloba. Ciência e Agrotecnologia, 43: e000319, 2019

LÓPEZ-OVEJERO, R. F. et al. Frequency and dispersal of glyphosate-resistant sourgrass (Digitaria insularis) populations across Brazilian agricultural production areas. Weed Science, 65: 285-294, 2017.

MAROCHI, A. et al. Managing glyphosate-resistant weeds with cover crop associated with herbicide 
rotation and mixture. Ciência e Agrotecnologia, 42: 381-394, 2018.

MEROTTO JR., A. et al. Interferência das plantas daninhas sobre o desenvolvimento inicial de plantas de soja e arroz através da qualidade da luz. Planta Daninha, 20: 9-16, 2002.

MONKS, D. W.; OLIVER, L. R. Interactions between soybean (Glycine max) cultivars and selected weeds. Weed Science, 36: 770-774, 1988.

NORDBY, D. E.; ALDERKS, D. L.; NAFZIGER, E. D. Competitiveness with weeds of soybean cultivars with different maturity and canopy width characteristics. Weed Technology, 21: 1082-1088, 2007.

PETERSON, M. A. et al. The challenge of herbicide resistance around the world: a current summary. Pest Management Science, 74: 2246-2259, 2018.

RAIMONDI, M. A. et al. Weed interference in cotton plants grown with reduced spacing in the second harvest season. Revista Caatinga, 30: 1-12, 2017.

RAMBO, L. et al. Rendimento de grãos da soja em função do arranjo de plantas. Ciência Rural, 33: 405 $-411,2003$.

SAMMONS, R. D.; GAINES, T. A. Glyphosate resistance: state of knowledge. Pest Management Science, 70: 1367-1377, 2014.

SOUSA, B. T. et al. Effectiveness of nanoatrazine in post-emergent control of the tolerant weed Digitaria insularis. Journal of Plant Protection Research, 60: 185-192, 2020.

TAKANO, H. K. et al. Spread of glyphosateresistant sourgrass (Digitaria insularis): Independent selections or merely propagule dissemination? Weed Biology and Management, 18: 50-59, 2018.

WOODS, S. J.; SEARINGIN, M. L. Influence of simulated early lodging upon soybean seed yield and its components. Agronomy Journal, 69: 239-242, 1977.

ZANON, A. J. et al. Desenvolvimento de cultivares de soja em função do grupo de maturação e tipo de crescimento em terras altas e terras baixas. Bragantia, 74: 400-411, 2015. 